\author{
М. С. Гнатюк, К. А. Походун, Л. В. Татарчук, О. Б. Ясіновський \\ ДВНЗ “Тернопільський державний медичний університет \\ імені I. Я. Горбачевського МОЗ Украӥни”
}

\title{
ОСОБЛИВОСТІ ЗАСВОЄННЯ ПРАКТИЧНИХ НАВИЧОК ЛІКАРЯМИ ХІРУРГІЧНИХ СПЕЦІАЛЬНОСТЕЙ ПРИ ВИВЧЕННІ ЕНДОСКОПІЧНОЇ ХІРУРГІЇ
}

\author{
M. S. Hnatjuk, K. A. Pochodun, L. V. Tatarchuk, O. B. Yasinovsky \\ I. Horbachevsky Ternopil State Medical University
}

\section{PECULIARITIES OF THE PRACTICAL SKILLS MASTERING OF DOCTOR-SURGEONS AT STUDYING OF ENDOSCOPIC SURGERY}

\begin{abstract}
Мета роботи - покращання освоєння практичних навичок при вивченні ендоскопічних хірургічних втручань.
Основна частина. Проведено педагогічний експеримент з двома групами лікарів, які вивчали ендоскопічну хірургію. Перша група після ознайомлення з теорією ендоскопічної хірургії приступала до виконання ендоскопічних операцій на тваринах. Друга група після вивчення теорії тренувалася у тренажерному залі та приступала до операцій на тваринах. Встановлено, що лікарями першої групи при виконанні операцій та маніпуляцій на тваринах допущено 27,5 \% помилок, а другою групою - 11,25 \%.

Висновок. Отримані результати проведеного дослідження свідчать, що найбільш адекватно та повноцінно освоюють практичні навички з ендоскопічної хірургії лікарі-курсанти, які навчаються поетапно з освоєнням необхідного мінімуму теоретичних знань, із відпрацюванням практичних навичок у тренажерному залі, з проведенням оперативних втручань на експериментальних тваринах та детальним аналізом допущених помилок під час операцій, ускладнень, наслідків у різні строки післяопераційного періоду та хірургічних коригуючих впливів для їх усунення.
\end{abstract}

Ключові слова: практичні навички; ендоскопічна хірургія.

The aim of the work - improving the mastering of practical skills at studying of endoscopic surgical interventions.

The main body. A pedagogical experiment was conducted with two groups of doctors who studied endoscopic surgery. The first group after getting acquainted with the theory of endoscopic surgery and proceeded to perform endoscopic operations on animals. The second group, after studying the theory, trained in the training room and proceeded to animal surgery. It was established that physicians of the first group committed $27.5 \%$ of errors in performing operations and manipulations on animals, while the second group was $11.25 \%$ of mistakes.

Conclusion. The obtained results of the conducted research indicate that most of the adequately and fully mastered practical skills in endoscopic surgery, doctors who study in stages with the development of the necessary minimum theoretical knowledge, the development of practical skills in the training room, conducting surgical interventions on experimental animals and a detailed analysis of the admitted errors during operations, complications, effects in different periods of the postoperative period and surgical corrective actions to eliminate them.

Key words: practical skills; endoscopic surgery.

Вступ. Глобальні трансформації, що відбуваються у суспільстві, зумовлюють нагальну потребу суттєвих техногенних змін в освіті. Важливу роль при цьому відіграє пошук нових технологій, які суттєво пришвидшать адекватну підготовку висококваліфікованих спеціалістів 3 якісно новим ступенем знань [1, 2].
В останні десятиліття інтенсивно розвиваються нові хірургічні технології, серед яких ендоскопічна хірургія, що є одним із найбільших досягнень клінічної медицини. Ендоскопічна хірургія усе ширше використовується лікарями різних хірургічних спеціальностей, оскільки дозволяє досягти максимальних результатів при мінімальній травма-

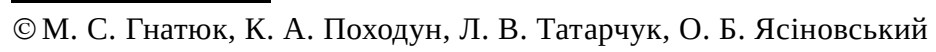


тичності. Варто зазначити, що на сьогодні хірургічні ендоскопічні методи широко застосовуються у різних хірургічних галузях.

При вивченні ендоскопічної хірургії лікар-курсант повинен мати не тільки глибокі теоретичні знання, а й повноцінно вдосконалити та освоїти практичні навички. Спеціальна апаратура та інструменти, електронні прилади, що дозволяють виконувати малотравматичні ендоскопічні втручання, вимагають від хірургів не тільки додаткових знань, а й нових навиків роботи з вказаним обладнанням.

У підготовці висококваліфікованого спеціаліста ендоскопічної хірургії важлива роль відводиться засвоєнню та оволодінню цілого ряду практичних навичок, які пов’язані зі запитами сучасної клініки і допомагають повноцінно виконувати алгоритми різних ендоскопічних оперативних втручань. Повноцінне засвоєння практичних навичок суттєво розширює кругозір лікаря, опанування ними сприяє своєчасному та грамотному наданню невідкладної допомоги в екстремальних ситуаціях. Адекватне засвоєння практичних навичок інтенсифікує засвоєння нових знань, стимулює цікавість до хірургічних знань, викликає активну діяльність мислення [3, 4].

Важливим при вивченні ендоскопічних втручань $€$ пошук інноваційних технологій навчального процесу, які б дозволили підготувати кваліфікованих спеціалістів даної галузі.

Необхідно вказати, що до сьогодні відсутні адекватні, повноцінні методи та системи підготовки кадрів для ендоскопічної хірургії.

Мета роботи - покращення освоєння практичних навичок при вивченні ендоскопічних хірургічних втручань.

Основна частина. Для оцінки освоєння практичних навичок при вивченні ендоскопічних оперативних втручань проводився педагогічний експеримент з 16 лікарями-курсантами, які навчалися на курсах ендоскопічної хірургії у навчальному центрі малоінвазивних оперативних технологій при ДВНЗ “Тернопільський державний медичний університет імені І. Я. Горбачевського МОЗ України”. Вказані лікарі-курсанти були розділені на 2 групи: 1 група нараховувала 8 осіб, у яких навчання починалося 3 вивчення теорії: сучасні моделі апаратури, спеціальний та допоміжний інструментарій, специфіка його обробки і стерилізації, а також анатомо-топографічне обгрунтування малоінвазивних оперативних втручань, особливості анестезіологічного забезпечення, показання і протипоказання до вказаних операцій, техніка виконання малоінвазивних оперативних втручань. Після теоретичного вивчення вказані особи приступали до виконання оперативних втручань на біологічних моделях, тобто тваринах.

2 група також нараховувала 8 осіб, які після теоретичного вивчення основ ендоскопічної хірургії приступали до тренування на тренажерах, розміщених у тренажерному залі навчального центру малоінвазивних оперативних технологій. Лікарікурсанти 2 групи спостережень засвоювали та вдосконалювали принципи роботи 3 ендоскопічним інструментарієм, вивчали та освоювали техніку в’язання інтра- та екстракорпоральних вузлів. Після навчання та праці у тренажерному залі дана група лікарів-курсантів приступала до виконання малоінвазивних оперативних втручань із використанням ендоскопічної техніки на тваринах.

Кожен лікар-курсант повинен був виконати на дослідних тваринах в експериментальній операційній діагностичні лапаро- та торакоскопію, холецистектомію, спленектомію, нефректомію, роз’єднання злук, здійснити екстра- та інтракорпоральні вузли і шви.

Варто також вказати, що в обох групах лікарівкурсантів перед виконанням навчальних оперативних втручань на експериментальних тваринах проводилося детальне вивчення алгоритму оперативних втручань та особливостей їх виконання на біологічних моделях.

Після виконання ендоскопічних операцій кожне оперативне втручання на експериментальних тваринах детально розглядалося на семінарських заняттях, де аналізувалися помилки, які допускали учасники операції в алгоритмі виконання того чи іншого оперативного втручання, ускладнення і їх наслідки під час операції, у ранньому та віддаленому післяопераційних періодах, а також ендоскопічні методи корекції допущених помилок та їхніх ускладнень.

Усестороннім аналізом помилок, допущених під час виконання вказаних ендоскопічних лікарських маніпуляцій та оперативних втручань на експериментальних тваринах, виявлено, що лікарями першої групи було допущено 22 помилки, що склало $(27,5 \pm 0,6)$ \% від усіх здійснених маніпуляцій та операцій.

У 2 групі при виконанні ендоскопічних маніпуляцій та оперативних втручань лікарями-курсантами було допущено 9 помилок, що склало $(11,25 \pm 0,30)$ \% від усіх здійснених маніпуляцій та операцій. Між наведеними відсотками помилок виявили виражену статистично достовірну $(\mathrm{p}<0,001)$ 
різницю. При цьому попередня цифрова величина перевищувала останню на 16,25 \%. Отримані та проаналізовані дані свідчили, що лікарі-курсанти, які поетапно здійснювали освоєння практичних навичок з ендоскопічної хірургії, допускали значно менше помилок в алгоритмах виконання ендоскопічних маніпуляцій та оперативних втручань на біологічних моделях порівняно з лікарями-курсантами першої групи спостережень.

Висновок. Отримані результати проведеного дослідження свідчать, що найбільш адекватно та

\section{Список літератури}

1. Ахтемійчук Ю. Т. Практичні навички з оперативної хірургії / Ю. Т. Ахтемійчук, В. П. Пішак, О. М. Слободян. - Чернівці : Місто, 2005. - 152 с.

2. Никоненко О. С. Нові організаційні форми післядипломної підготовки лікарів: досвід впровадження та проблемні питання / О. С. Никоненко, С. Д. Шаповал, С. М. Дмитрієва // Проблеми інтеграції української медичної освіти у світовий освітній простір : матеріали конф., 21-22 травня 2009 р. - Тернопіль : Укрмедкнига, 2009. - C. 41-42.

\section{References}

1. Akhtemiichuk, Yu.,T., Pishak, V.P., \& Slobodian, O.M. (2005). Praktychni navychky z operatyvnoi khirurhii [Practical skills on operative surgery]. Chernivtsi: Misto [in Ukrainian].

2. Nykonenko, O.S., Shapoval, S.D., \& Dmytriieva, S.M. (2009). Novi orhanizatsiini formy pisliadyplomnoi pidhotovky likariv: dosvid vprovadzhennia ta problemni pytannia [New organizational forms of postgraduate medical training: experience of implementation and problem questions]. Problemy intehratsii ukrainskoi medychnoi osvity u svitovyi osvitnii prostir. Materialy konf. 2122 travnia 2009 r. Ternopil: Ukrmedknyha [in Ukrainian]. повноцінно освоюють практичні навички з ендоскопічної хірургії лікарі-курсанти, які навчаються поетапно, з освоєнням необхідного мінімуму теоретичних знань, з відпрацюванням практичних навичок у тренажерному залі, з проведенням оперативних втручань на експериментальних тваринах і детальним аналізом допущених помилок під час операцій, ускладнень, наслідків у різні строки післяопераційного періоду та хірургічних коригуючих впливів для їх усунення.

3. Особливості засвоєння практичних навичок при вивченні оперативної хірургії та топографічної анатомії / М. С. Гнатюк, Ю. О. Данилевич, Р. М. Гнатюк, О. Б. Слабий // Медична освіта. - 2007. - № 1. - С. 40-42.

4. Попович Ю. Л. Техніка хірургічних операцій / Ю. Л. Попович, К. О. Діамантопуло. - Івано-Франківськ, 2005. - 348 c.

3. Hnatiuk, M.S., Danylevych, Yu.O., Hnatiuk, R.M., \& Slabyi, O.B. (2007). Osoblyvosti zasvoiennia praktychnykh navychok pry vyvchenni operatyvnoi khirurhii ta topohrafichnoi anatomii [Features of mastering of practical skills in the study of operative surgery and topographical anatomy]. Medychna osvita - Medical Education, 1, 40-42 [in Ukrainian].

4. Popovych, Yu.L., \& Diamantopulo, K.O. (2005). Tekhnika khirurhichnykh operatsii [Surgical techniques]. Ivano-Frankivsk [in Ukrainian]. 